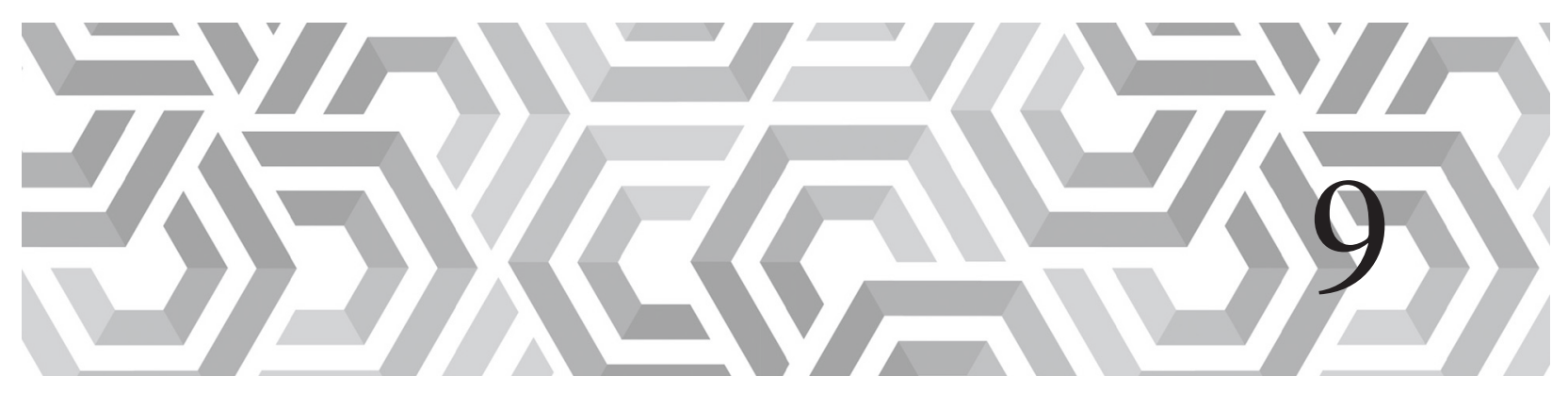

\title{
International Relations and Political Sociology
}

\author{
Salvador Mateos and Álvaro Morcillo Laiz
}

Sociologists have traditionally paid scant attention to International Relations (IR) as a social-scientific discipline ${ }^{1}$. A small, but telling piece of evidence on sociologists' lack of interest in IR is the absence of an article on this subject in the fifteen-volume International Encyclopedia of Social Sciences (Sills, 1968). The successor edition, extended to twenty-six volumes, included only two entries on IR and a few more on area studies (Smelser \& Balter, 2001); the most recent edition ignored IR altogether, containing not a single entry on the discipline, but included area studies (Wright, 2015). This evidence suggests not only that sociologists' ignorance of IR is widespread but also that it has remained fairly constant across time. At least some IR scholars are conscious of their lack of impact on other disciplines in the social sciences, and regret this situation. Almost twenty years ago, in an unsubstantiated remark, two senior authors admitted that IR employs theory and other ideas from sociology, economics, and political science, but has 'little impact on debates in the other social sciences' (Buzan \& Little, 2000, p. 3). These regrets were not new, though. Fifteen years earlier, another noted British IR scholar had already admitted that, in terms of theory, IR had been 'an absorber and importer, not a producer in its own right' (Halliday, 1985, p. 408). These claims were based on intuitions, but their pessimism is symptomatic of what may be called the 'principle of mutual ignorance'.

Arguably, the way in which IR defines its object isolates the discipline from other social sciences. IR, in particular realism and liberalism, its two mainstream paradigms, posit that fundamental differences exist between politics within sovereign nation-states and politics among nation-states. In this latter sphere, anarchy reigns, making a separate, specific IR theory necessary. In other words, IR assigns a heightened ontological significance to what elsewhere would be considered legal concepts, like borders and sovereignty, whose validity would be subject to empirical tests (rather than presuming their causal 
efficiency, as most IR mainstream theory does). These assumptions limit the relevance of its scholarship for sociology and possibly for the social sciences as a whole.

In the past, most of the sociological blood in IR ran through the veins of realism, one of the three disciplinary paradigms cultivated by the disciplinary mainstream. Paradigms are widely used in IR to classify scholarship (and authors) and we will explore them later in more detail. Here, brief definitions will suffice. The realist paradigm possesses a clear Weberian descent (M. J. Smith, 1986, pp. 23-53; Turner, 2008), although IR scholars were long uninterested in this ancestry, as in many other aspects of the discipline's intellectual history. As Duncan Bell noted, this may have been a further expression of a general 'lack of historical sophistication and awareness' (Bell, 2001, p. 120).

While realism's debts to Weberian thought are now well established, what a Weberian element means for the newer coinage of the paradigm, known as neorealism, is less evident, although broadly sociological thought functionalism - is a perceptible element of it. The connections to sociology are dimmer in neoliberalism, a paradigm that assumes the realist premise of anarchy while focusing on the possibilities for economic coordination among states; neoliberals admit that these possibilities are limited and subject to certain constraints, but emphasize their existence. By contrast, connections to sociology are robust in the case of the third paradigm, reflectivism. This label refers to an internally differentiated group of non-positivist approaches to IR. Among them we find constructivism (Onuf, 1989; Wendt, 1999), together with others that square even more explicitly with the sociological tradition, like Marxism (Cox, 1983; Rosenberg, 1994) and critical theory (Linklater, 1989; Linklater, 2011).

In this chapter we argue that sociologists and IR scholars ignore each other, despite wide areas of conceptual (power, conflict, state) and substantive (organizations, development) common interests. IR disciplinary history allocates no significant role to sociology in its formation, although an examination of the two main paradigms reveals this to be only partially accurate. By contrast, for the 'reflectivist' paradigm, sociology is crucial not only for Marxists and Critical theorists, but also for constructivists, who in the international realm employ the ideas of authors placed firmly in the sociology and social theory tradition. However, IR scholars from this paradigm have thus far made no impact on the sociological and social theory traditions from which they draw; only a few, specific and self-contained sociological debates take note of IR.

A number of caveats need to be mentioned. First, this chapter mainly focuses on sociology and IR, although there will be occasional explicit references to political sociology. In accordance with our expertise, our focus is such that 'sociological' will frequently mean Weberian. As for the IR side of the chapter, the focus is on one part of IR, IR theory, with occasional consideration of area studies. Second, for reasons of convenience, we will refer here to IR as a discipline, although sound reasons exist to contest this. In the United States, the home country of the discipline (Hoffmann, 1977; S. Smith, 2000), IR is a subfield of political science, in addition to American politics, comparative politics, and political theory. However, in many countries IR is considered an academic discipline alongside political science; accordingly, departments exist separately (A. B. Tickner \& Wæver, 2009). Third, the chapter reduces the enormous variety of IR scholarship to a limited, mostly American, subset that comprises its mainstream. 'Mainstream' here means IR as it is practiced in the top fifty US universities and in a few others, mainly in Anglo-Saxon countries, and as it is published in major IR journals, such as International Organization and World Politics. The British, French, and other 'national schools' will only make occasional appearances.

The first section explores the historiography of IR, in particular the narrative that IR 
scholars employ to tell the 'history' of the discipline: the so-called IR debates, paying attention to the role of sociology in the historiography of IR. The second section examines the two mainstream paradigms, while the third emphasizes 'reflectivist' approaches and, in particular, constructivism. In the conclusion, we point to specific topics where an intellectual exchange is taking place, and suggest topics for further research.

\section{HOW IR TELLS ITS STORY: A MONOLOGUE?}

There is little difficulty in showing that the dialogue between sociology and IR is scant; indeed, the only challenging tasks are to account for this limited exchange and identify the few instances of dialogue. The available bibliography does not help as much as would be desirable. Book-length accounts of the history of IR are relatively new and rare; they cover specific countries and time periods and are constructed from certain, sometimes controversial, departing assumptions (Schmidt, 1998; Guzzini, 1998; Bell, 2001). Equally rare are valuable attempts that go beyond personal experience and common sense, instead combining insights from the sociology of science with empirical, systematic evidence (Wæver, 2013; Wæver, 1998; Baron, 2014). Until the late 1990s, IR histories one-sidedly emphasized the idealism and pacifism of the discipline's early years, rather than studying the origins of IR as a branch of US political science dedicated to colonial government and administration (Long \& Schmidt, 2006; Schmidt, 2008) and even interracial relations (Vitalis, 2015). Such problems possess obvious connections with imperialism. However, 'very few saw this [the study of colonial government] as international relations' (Wæver, 1996, p. 151). Incidentally, imperialism was an enterprise in which sociology was also deeply involved, in the form of a sociology of colonialism
(Steinmetz, 2013b; Steinmetz, 2013a). In brief, historiographical and sociological research on IR as a discipline is meager; the situation is probably only slightly better than that of political theory in the US twenty-five years ago (Gunnell, 1991). This paucity is acknowledged even by IR authors (Schmidt, 2013; Wæver, 2013; Schmidt, 1998; Wæver, 1998).

To a certain extent the 'impoverished condition' (Schmidt 2008, p. 676) of IR historiography reflects the fact that the disciplinary history has not been written by specialists in relevant fields like intellectual history, history of ideas, and sociology of social sciences. Actually, the largest share of the relevant bibliography in the history of IR comes from IR scholars specialized in something else. Consequently, the occasional essays about the state of IR that constitute most of the bibliography on IR are informed by personal experiences and intellectual loves and phobias, rather than by systematic research, reading, and comparison. Thus, the 'historiography' of IR reunites the yields of its practitioners' pastime or, even worse, the weaponry used in the attempts to advance professional ambitions and agendas and to preclude the cultivation of alternative visions. In the best instances, the actual intention of contributing to the disciplinary history is to diagnose problems and propose new directions to follow, to paraphrase Brian Schmidt (2010, p. 3423). In sum, there are, as some have claimed (Schmidt 2010, p. 3427), 'grounds for questioning whether' IR history really is now 'a full-fledged subfield'.

More often than not, these pieces have been published as interventions in one of the conspicuous IR 'debates', around which the customary histories of IR are organized. For more than half a century the 'debates' on which is the best paradigm to understand international relations, and produced IR theory, have operated as a replacement for disciplinary histories. In reality, the 'debates' are mainly a string of interventions that, dressed as presidential addresses, articles, book 
chapters, and special issues, ostensibly offer an account of the field's history (Gurian, 1946; Thompson, 1955; Kaplan, 1966; Hoffmann, 1977; Keohane, 1988; Lapid, 1989; Tim Dunne, Hansen, \& Wight, 2013).

The 'debates' narrative, a simplifying rationalization, was 'mainly invented for specific presentational purposes, teaching, and self-reflection' (Wæver, 1996, p. 161). In fact, the 'debates' narrative has been defended as an instrument that can help students visualize the 'progress' of the discipline or, at least, situate in time the rise of the main IR theories. For some, they are the only available device to provide IR with intellectual and historical coherence (Wæver, 2013, pp. 317-19; Wæver, 1996, 174-5).

To briefly summarize the 'debates' here is necessary because doing so offers valuable insights on how IR thinks about itself and its relations to other social sciences. More specifically, the 'debates' make apparent the limited importance that IR scholars attribute to sociology, political science, history, etc. for the development of the discipline. According to one 'foundational myth' (Carvalho, Leira, \& Hobson, 2011, pp. 745-55), IR began after WWI as an intellectual enterprise characterized by a preoccupation with peace and international organizations (IOs). Its practitioners were mainly lawyers and activists committed to preventing further wars. These goals and the faith in the law and IOs as means to prevent armed conflict would have made these IR scholars deserve the label of 'idealists'. In the 1930s and 1940s, a different paradigm gained importance as epochal changes led to WWII; the end of the war marks the victory of realism in the 'first debate'. Rather than examining the good or evil nature of man, the next debate centered on methodological problems.

Realists, who had emphasized both history, as the object IR scholars should study, and scholars' ability to judge properly, were engulfed in the positivist renewal in political science, the so-called behaviorist revolution (Easton, 1969; Dahl, 1961a), with its emphasis on scientificity and value-neutrality. During the second debate, in the early 1960s, the partisans of behaviorism brought to IR an emphasis on law-like regularities, universality, and verifiability, but also a new understanding of the state and its rationality, conceived as instrumental rationality rather than as realists' more substantive idea of prudence (Morgenthau, 1954). Despite the differences, the door to IR opened up for rational choice (Keohane 1988, pp. 65-132), which was woven into a new idealism, known in IR as liberalism and its varieties (Moravcsik, 2008, pp. 240-44).

At least since the 1970s, the third party to this debate was Marxism. The refurbished versions of realism, structural realism or, as it is more widely known, 'neorealism' (Waltz, 1979), and of idealism, neoliberalism, benefited from an alleged complementarity, while being challenged during the third or inter-paradigm debate by Marxist and, since the 1980s, by post-modern IR (Lapid, 1989). By the end of the 1980s, the 'debates' narrative had even become useful for arguing that something like a unity of the discipline existed.

Nowadays, neoliberalism and neorealism occupy the IR mainstream. The relatively small differences between these two result in the so-called neo-neo debate. Since both theories are thoroughly rationalist, they offer, from a political point of view, limited possibilities for exercising criticism. Being so alike, neorealism and neoliberalism encounter the opposition of 'reflectivism'. Under this label we find a wide range of alternative, thoroughly sociological, theories and approaches to IR, from Marxism and critical theory to constructivism, feminism, poststructuralism, and postmodernism. In this fashion, 'reflectivist', constructivist, and radical IR would oppose a 'rationalistic' mainstream IR in which neoliberalism and neorealism, occupied in their own neo-neo exchanges, would be placed. According to Wæver this opposition is explored a post-modern, fourth debate (2013, pp. 317-19, 321). 


\section{RELATIONS BETWEEN IR AND SOCIOLOGY - THE MAINSTREAM}

The preceding paragraphs revealed the ways that IR scholars have seen and constructed their discipline in isolation. The 'debates' and, to a lesser extent, the historiography of IR, offer a vision of the disciplinary history that leaves aside other fields of study, denying them a significant formative role, and conveying an incomplete, if not distorted, image of IR's subject matter. In reality, IR has borrowed freely from the troves of knowledge possessed by sociology, political science, history, economics, and other disciplines. Admittedly, even scholars within the mainstream IR paradigms regularly acknowledge occasional loans from specific subfields within political science, such as American politics (Martin \& Simmons, 2013, p. 327), comparative politics (Dahl, 1961b), political theory (Easton, 1965), and from economics (Keohane, 1984); rational choice methods are also crucial (Snidal, 2008). IR scholars also concede that an English, eminently historical and sociological school exists within IR (Keohane, 1995; Goldstein \& Keohane, 1993, p. 9), that valuable knowledge on IOs has been gleaned from 'the insights of political science as well as sociology' (Martin \& Simmons, 2013 , p. 339). In general, the future of IR is difficult to imagine outside political science (Wæver, 2013, pp. 310-12). Despite the widespread awareness of these 'loans', nobody has conducted a full-fledged investigation of IR's numerous links to other disciplines. Such an inquiry should tackle the question of what the 'loans' mean for the central assumptions of mainstream IR, like the idea of anarchy, as well as for the pretensions of IR being a separate social-scientific discipline.

One thing is known. The connections between sociology and IR vary in importance depending on which IR paradigm we look at. We have already mentioned that, between the two mainstream paradigms that set the tone in IR, neorealism possesses the stronger sociological, or at least Weberian, roots. These go back to its antecedent formulation, realism. Realism and most of IR, wittingly or not, takes from Weber the ideal-type of the state as the organization that successfully claims a monopoly over violence. Unfortunately, realism then isolates this idea, the monopoly of violence, from its perceived legitimacy among those subject to the state's authority, and then from the rest of Weber's 'Basic concepts' (Morcillo \& Schlichte, 2015, pp. 4-9). In a similar fashion, when (neo) realists view international politics as conflict, they reiterate Weber's conviction that Kampf (literally, fight) is part of all social relations. The crucial difference is that Weber did not assume that conflict appears suddenly when domestic politics are left behind and state borders are crossed. Weber, a German author, is mentioned only rarely in the early American writings of Hans Morgenthau, who was German-born and the most influential realist in IR, a precautionary measure that perfectly made sense in the years following the defeat of National Socialism. Still, Morgenthau's sentences testify to his debt to Weber. Here there is only space for one example: 'Politics is a struggle for power over men' (Morgenthau, 1946, p. 167) vs. '... the state is a relationship of rule (Herrschaft) by men over men ...' (Weber, 1994, p. 311; we have modified some translations). In recent years, realism's Weberian inspiration has been firmly established (Turner \& Mazur, 2009; Turner, 2008; M. J. Smith, 1986). As a result, the most recent accounts of realism pay attention to the connection (compare Wohlforth, 2008; and Donnelly, 2008; with Lebow, 2013). When the paradigm was predominant, many prominent realists held favorable opinions of sociology (Thompson, 1955, pp. 448-50).

If we move on to neorealism and its masterpiece, Kenneth Waltz's Theory of International Politics (1979), we find again the omnipresence of conflict: 'with each state deciding for itself whether or not to use force, war may at any time break out' (Waltz, 1979, p. 102). Many more Weberian traces can be found and explained by the continuities 
between realism and neorealism, such as the constant reminders of the discrepancies between intentions and actual results (Waltz, 1979, pp. 65, 90, 119, 192). But neorealism, unlike realism, contains other marks of sociology's impact on IR. As its critics point out, neorealism combines a deductionist form of structuralist reasoning, and of systems theory (Buzan, Jones, \& Little, 1993). Structure is at the center of Waltz's reasoning, when he writes that 'In defining structures, $[\ldots]$ political scientists do not ask about the personalities and the interests of the individuals occupying various offices. [...] they want to know [...] how people's behavior is molded by the offices they hold' $(1979$, p. 81). As for how crucial the concept of 'system' is to neorealism, a quote from chapter five of Theory of International Politics will suffice: 'I have now defined the two essential elements of a systems theory of international politics - the structure of the system and its interacting units' (1979, p. 99). These interacting units are the 'like-units', supposedly comparable to sovereign states (1979, p. 96). Unfortunately, Waltz does not attempt to situate his magnum opus within a specific tradition of social or political thought, while in the introduction he draws numerous comparisons with physics and economics. David Easton's analogous attempt to apply another variety of systems theory to political theory has been carefully examined by John Gunnell (2013), but a comparable study for IR is missing. In the cases of other IR theorists, such as Morton Kaplan (1957), the debt to systems theory is more obvious, but his contemporary influence is negligible.

The connections of neoliberalism to sociology are faint. Of course, neoliberalism is strongly dependent on, not to say an application of, rational choice theory, which is remotely connected to Weber's investigations on rationality and methodology (Norkus, 2000; Leonard 2010, pp. 102, 167, 230). However, the strongest link between neoliberalism and sociology is through IOs, whose contemporary study is reliant on the sociology of organizations, which in some of its versions still relies on Weber. In addition, neoliberalism draws from the theories of public goods, market failure, and functionalism. The variety of functionalism used most by neoliberals was first formulated by David Mitrany, a now-forgotten, Romanian-born author (on Mitrany and on functionalism in IR generally, see Steffek, 2015). The role of functionalism in neoliberalism becomes evident in the response to Waltz's neorealism (Buzan, Jones, \& Little, 1993); neoliberals emphasize the ability of international regimes to 'perform the valuable functions of reducing the costs of legitimate transactions, while increasing the costs of illegitimate ones, and of reducing uncertainty' (Keohane, 1984, p. 107).

Finally, the 'reflectivist' paradigm encompasses constructivism and other approaches to IR without much in common beyond being outside the two earlier, more 'rationalistic' paradigms. In many of these approaches, which differ in crucial aspects and sometimes even are mutually contradictory, sociology has wielded an undisputed influence. This is the case of the so-called English School (Butterfield \& Wight, 1966; Buzan, 2004; Timothy Dunne, 1998; Bull, 1977), whose view of international relations is not only more sociological, but also more historical than that of the mainstream. A comparable sociological sediment also distinguishes critical theory and Marxist IR. Most 'reflectivists' also recognize institutional, many would say cultural, diversity around the world, while in other paradigms the departing assumptions imply a large measure of homogeneity among states.

\section{RELATIONS BETWEEN IR AND SOCIOLOGY - REFLECTIVISM}

Different Marxist approaches have played a role in the study of international relations. Any Marxist IR theory is founded on Karl Marx 
and Friedrich Engels' prophecy of global markets. According to The Communist Manifesto, 'The discovery of America, the rounding of the Cape, opened up fresh ground for the rising bourgeoisie' (Marx \& Engels, 1959 [1848], p. 463). As capitalism arrives to every corner of the world, further transformations, as well as possibilities for conflict, ensue: 'the communists emphasize the interests of the proletarians, unchanged by their nationality' (Marx \& Engels, 1959 [1848], p. 474). To provide answers to some of the questions Marx and Engels left unsolved, a successive generation of Marxists wrote some of the earliest modern classics of IR as theories of global capitalism and imperialism (Hilferding, 1981 [1910]; Lenin, 1937 [1916]), both incited by a non-Marxist radical (J. A. Hobson, 1902). Among the contemporary adaptations of Marxism to IR, the earliest and possibly most influential was Immanuel Wallerstein's world-systems theory, which argues that capitalintensive production systems are the basis used by core states to establish a hegemony that then expands to commerce and finance (1974). However, Wallerstein's work has been criticized for its lack of a state theory and its functionalist undertones, even by other Marxists, who have tried to overcome these flaws (Teschke, 2003; Lacher, 2006). A further influential Marxist alternative to worldsystem theory in IR has been Robert Cox's adaptation of Antonio Gramsci's theory. Instead of (neo)realists' power, hegemony would explain how the 'structure of accumulation' is projected abroad thanks to the agency of the hegemonic class of a hegemonic state, universalized via international private bodies (Cox, 1983; Cox, 1981). Criticisms of both neo-Gramscian theory and world-systems theory have been made by a group of Marxist scholars, most of them based at English universities, although a frequently Marxist, and in any case sociologically informed, IR has existed in West German universities since the 1970s (Senghaas, 1969; Senghaas, 1971; Krippendorff, 1972; Senghaas, 1974; Krippendorff, 1975).
This latest generation of Marxists heeded Fred Halliday's plea for a 'necessary encounter' between historical materialism and international relations (1994, Chapter 4). Scholars such as Justin Rosenberg, Benno Teschke, and Hannes Lacher attempted to overcome the flaws of Marx and Engels' incomplete account of 'international relations'. One of their aspirations has been to demonstrate that diverse modes of production and models of social structures correspond to different geopolitical systems, running against neorealists' assumption of like-units across time and space (Rosenberg, 1994; Teschke, 2008, p. 178). While Rosenberg has recently become the central figure in a group of scholars interested in applying Trotsky's concept of 'uneven and combined development' (2013; Trotsky, 1932, Chapter 1), the most successful of all recent Marxist attempts to tackle international relations has come from outside the discipline (Hardt \& Negri, 2000).

Close to this Marxist IR, we find IR authors committed to historical sociology. The intellectual ferment came originally from major 'neo-Weberian' US and British historical sociologists such as Theda Skocpol, Charles Tilly, and Michael Mann, as well as from Anthony Giddens's structuration theory. The proposal of scholars such as John Hobson, Stephen Hobden, and George Lawson is to write a historical sociology of international relations, but this time authored by IR scholars rather than sociologists. IR scholars sought to problematize the dominant conception of the state in IR, in particular realist IR. Instead of accepting that for international relations all states could be considered homogenous in terms of their interest in maximizing security and wealth, the historical sociology of international relations resorted to the sociology of the state to demonstrate how the different domestic social configurations that sustain a state make a substantial difference for its international relations, a concern they shared with Marxists (J. M. Hobson, Lawson, \& Rosenberg, 2010, p. 3362). The other central ambition of these authors, and 
especially of Hobden and Hobson (2002), was to get rid of the customary treatment of time in IR scholarship. In this respect, the problems they diagnosed in IR were multifarious: to assume that the present is causally independent even from the immediate past, and to project current conditions toward the past, assuming that intrinsically historical actors like the state (Waltz's 'like-units') are homogenous and that, therefore, accounts of international relations would be valid 'now and then'. In plain words, the usual treatment of time in IR gives rise to different 'illusions' (J. M. Hobson, 2002, p. 6). It is important to underline, at least from the perspective of this chapter, that these IR authors-turnedhistorical sociologists were initially inspired by Weber, in addition to Marx (J. M. Hobson et al., 2010, pp. 3363-64). More recently, the most successful historical sociologist in IR, Hobson, has turned his attention to a postcolonial critique of IR (2012).

In Europe, some IR scholars have consciously attempted to apply non-Marxist social theory to IR recently, but national divergences are significant. The English School, the best known of these streams of scholarship, has already been mentioned. A small country like Denmark has produced a remarkable instance of sociological IR research, the Copenhagen School, specialized in the sociologically informed study of security (Buzan, Wæver, \& Wilde, 1998; Wæver, 2010; Wæver, 2011). In France, the interest in sociology and in area studies has remained constant and explicit, possibly under the lasting spell of Raymond Aron (1962), a realist. Actually, 'the close relationship to sociology, philosophy, and anthropology' has been considered 'the main strength of French IR' as well as the vigorous area studies (Wæver 1998, p. 709; Friedrichs \& Wæver, 2009, pp. 268-69; Breitenbauch, 2013). Since the 1970 s, a significant number of German IR scholars have received some sociological training, to some extent by the aforementioned generation of Marxists; their work focuses on peace research, i.e. the Arbeitsgemeinschaft Kriegsursachenforschung
(AKUF), a Hamburg-based group studying the origins of war, and development studies. Most recently, Matthias Albert has proposed systems theory and, in particular, differentiation theory for IR (Albert, Buzan, \& Zürn, 2013; Buzan \& Albert, 2010). Short of valiantly 'addressing IR theory as social theory' (Albert \& Buzan, 2013, p. 117), other authors have argued that the crucial IR discussion on power and authority could benefit from a thorough examination of Weber's concept of domination (Simmerl \& Zürn, 2016; Morcillo \& Schlichte, 2015). One main argument that would result from such an inclusion is that rational domination better explains much of what sociological institutionalists and allied IR scholars call 'diffusion of norms'. The emphasis on persuasion distracts from the unequal distribution of knowledge among actors in the international domain. Within German IR, the reinforced interest in sociology is now shared by scholars working on a wide range of topics, using different paradigms (Stetter, 2013).

Switching now from a national to a thematic perspective, the topics of interest for sociologically minded IR scholars in Europe include security, which has also been studied from a Foucaultian perspective (Bigo, 1996; Bigo, 2011), 'globalization' (Bayart, 2004), and 'development', whose study has benefited from the aforementioned openness to sociology, as exhibited by IR scholars in the UK and France (Bliesemann de Guevara, 2012; Lottholz \& Lemay-Hébert, 2016). More recent is an interest in examining the staff employed in international organizations (Hensell, 2016; see also, from the perspective of international political economy, Seabrooke \& Wigan, 2016; Seabrooke \& Nilsson, 2015).

Much like the attempts to extend historical sociology, differentiation theory, and the concept of domination to the international realm, IR constructivism is also firmly anchored in sociology or, to be more precise, social theory. Nothing can be more expressive about this association than the title of the most influential book written by an IR constructivist, Social Theory of International Politics 
(Wendt, 1999). As the title suggests, constructivism takes pride in making this link. Such a full disclosure is coherent with constructivism's core ambition: to re-establish IR on a basis different from the reifications intrinsic to neorealism and neoliberalism, such as like-units, the centrality of power, and instrumental rationality. Constructivism aspires to turn them into what they are, more or less widely shared and enforced rules as well as specifications of actors' identities. Accordingly, IR constructivists are concerned with how rules are defined and interests invented anew in an ever-changing social world; they want to define and interpret reality, while neorealists and neoliberals take it as a given. Finally, constructivists employ social theory to argue about how important knowledge is for the actors they study, as well as for the constitution of agent and structure. By contrast, neorealism assumes a certain structure - anarchy - and is uninterested in knowledge; neoliberals espouse neorealists' structure, but focus on the opportunities for collaboration left by anarchy - 'Strategic interdependence is at least as fundamental' (Milner, 1991, p. 85). To exploit those possibilities requires only experts' instrumental knowledge. Substantive rationality remains a neglected topic in mainstream IR, in particular the conflicts among different types of rationality (but see Barnett \& Finnemore, 1999; Morcillo \& Schlichte, 2016).

Beyond this set of ideas shared by most constructivists, we find significant diversity. According to Emanuel Adler (2013, pp. 114-17), constructivist approaches can be classified according to the type of hermeneutics they use - objective or subjective - and the cognitive interest they pursue - control or emancipation. According to these distinctions, IR constructivists belong to one of four main types: modernist, modernist linguistic, radical, and critical. The first of these combines 'objective hermeneutics with a "conservative" interest in understanding and explaining social reality' (Katzenstein, 1996; Barnett \& Finnemore, 2004); the second maintains the same interest in 'control', but employs subjective hermeneutics, which pays attention to language as the means to examine consciousness (Kratochwil, 1988; Reus-Smit, 2013). Third, radical constructivists exhibit emancipatory ambitions for social knowledge and a subjective hermeneutics resulting from different mixes of poststructuralism and post-modernism (Ashley, 1984; J. A. Tickner, 2014). The fourth type entails constructivists committed to an emancipatory knowledge, but drawing on objective hermeneutics (Murphy, 2006; Rae, 2002).

Such a classification reveals which sociological authors and ideas bear on IR constructivism. Max Weber and Alfred Schütz are the precursors of 'objective hermeneutics', while modernist linguistic constructivism relies on philosophers like Martin Heidegger and Ludwig Wittgenstein. In the case of radical constructivists, their ideas are dependent on Jacques Derrida and Michel Foucault, just as those of critical constructivists build upon Jürgen Habermas's work (for a different, constructivist use of Habermas, which is widely influential in IR, see Risse, 2000). However, even if it is evident that Western social theory, particularly its postwar authors, has delivered the rationale and building blocs of the constructivist enterprise, its overall significance for IR constructivism is difficult to gauge. Since the historiography of IR is so sparse, it is unsurprising that an intellectual history centered on constructivism does not exist. We cannot offer one here.

Less expected is the nonchalant manner in which constructivists frequently deal with social theory and with the history of social thought. In constructivist IR, discussions of social theory classics are frequently based on secondary literature, namely handbooks and other summaries, leaving aside the works in which social theorists first put on paper their ideas. Thus, as the intellectual contexts in which they were first stated and basic aspects of their reception are lost, the precise meaning of concepts gets blurred. Similarly, the connections between different ideas and 
authors also go astray. These problems can be illustrated by the example of Weber. In a book chapter on constructivism (Adler, 2013), the author never mentions Weber when he argues that material and ideal interests exist; that there are other types of rationality beyond the instrumental; that Alfred Schütz inspired Peter Berger and Thomas Luckmann's The Social Construction of Reality; that one approach to science emphasizes explanation while an alternative approach aims to discern meaning; or that a logic of appropriateness ('ethics of conviction') frequently comes into conflict with a logic of consequences ("ethics of responsibility'). Interestingly, all these threads, which are basic tenets for most constructivists, can be traced back to the core of Weber's thought where, despite its difficulties and shortcomings, most constructivists would find a self-contained formulation of what it means not to take social reality as given.

Even more, this same author writes that Emile Durkheim 'abandoned' Weber's methodological individualism to focus on structural functionalism. From the perspective of the history of sociological ideas, this is not how Durkheim may be set in a meaningful relation to Weber. In any case, this is not how 'things happened' back then for, while the two scholars were aware of each other's existence, no trace of mutual influence can be found in their respective works, as long ago noted (Tiryakian, 1966). Another constructivist an IR scholar most familiar with social theory - aligns Weber with the adherents of 'political development' (Kratochwil, 2008, p. 453), synonymous with 'modernization'. In doing so, he reproduces a reading of Weber that was widespread in the 1960s and has long been discredited as biased and deprived of a textual basis (Cohen, Hazelrigg, \& Pope, 1975; Gilman, 2003; Tribe, 2007). To put it differently, IR constructivists rely heavily on different social theories, but they resort to this knowledge in an instrumental fashion, not interested in those theories by themselves, but as a means to undergird their approach to IR. This is legitimate, it leads to so-called 'creative misinterpretations' in the best of cases (Roth, 1971, p. 35); it may improve IR theory, and even empirical research, but does not enable IR theorists to engage in a debate with sociologists and, much worse, does not equip them to fully exploit what social theory offers to IR.

$\mathrm{Be}$ that as it may, the fact remains that constructivism and the broadly sociological reflectivist paradigm are not considered part of IR by the mainstream. Constructivist scholars are a minority within the top US political science departments $(6 \%)$ and in International Organization, the major IR journal, articles $(7 \%)$. If we consider all IO articles written using a constructivist paradigm or one open to such, then the proportion goes up to $21 \%$ (Subotic, 2017; Zarakol, 2017). This would turn the members of a reflectivist paradigm into a sizeable minority, but still a minority, and, furthermore, an internally extremely heterogeneous one. Globally, the IR mainstream is not the absolute majority of the profession, but it probably encompasses less than half of IR scholars worldwide (four-fifths of the mainstream IR scholars would be in the US, possibly more) (Maliniak, Peterson, \& Tierney, 2012, pp. 6, 26). In brief, reflectivism is the underdog within American IR and, therefore, globally. In addition, since it is internally diverse, it looks like a growing archipelago of 'postpositivist islands' (Ferguson \& Mansbach, 2016). Similarly, sociology could be said to be dispersed in an ocean of mainstream IR.

\section{CONCLUSION}

Studying the relations between IR and sociology confronts us with a paradox. If the largest segment of IR, the so-called mainstream, is analyzed, then we find only vestiges of sociology. If we discuss the rest of IR, we encounter long-standing sociological inroads into IR, as in the UK, France, and Germany, but we then leave aside the 
segment of the discipline that has greatest influence on the rest, which is also the only segment benefits, at least to a certain extent, from a global readership. Notwithstanding this, what appears to be the increasing significance of sociology for reflectivism, and therefore for IR as a whole, has a correlate in the mainstream, even if on a smaller scale. As successive waves of sociological inspiration brought Marx, Gramsci, Skocpol, and Schütz into the British IR journals outside the mainstream, eventually the presence of sociology in International Organization also (slightly) increased.

A sample of International Organization articles that includes every fifth volume between 1985 and 2015 reveals a progression from a total absence of sociological articles toward a still modest presence in the last five years. While in 1985 no article of International Organization cited the American Journal of Sociology or American Sociological Review, eight were cited in 2015. In the peak year, 2005, eighteen sociological articles were mentioned. In the last six volumes (2010-2015), there has been a greater tendency to cite sociological articles, with citations in a range from one (2010) to sixteen (2014) per year. A large share of these reflect the significance that neoinstitutionalism and John Meyer's Stanford School has had for IR scholarship on IOs and norm diffusion. If the study is expanded to include IR handbooks and encyclopedias, the pattern is confirmed: the IR mainstream is seldom interested in sociology, but when scholars from other paradigms and from outside the US are included, sociology begins to play a role, which becomes even larger if we move from IR to international studies. A parallel exercise in the other direction shows that, as limited as the value that the IR mainstream places on sociology, sociologists cite IR articles even more rarely, at least if only International Organization and World Politics the two major IR journals, are considered. The exceptions result mainly from the study of free trade areas as well as from the innovative human rights research in IR, which sociologists do use and cite. Incidentally, the strong interest of neoliberal and some constructivist IR in the sociology of organizations has not fully been reciprocated (Mateos \& Morcillo, 2017). Further possibilities for exchanges between IR scholars and sociologists would result from an enhanced attention in IR to topics with a long tradition in sociology and whose significance and international dimension has become obvious. Among these topics are the globalized professions such as scientists, managers, and artists; the staff of IOs, its training, life-stories, and life-styles; and global public intellectuals. So, what will happen now? Our guess is that IR scholars - and their journals, such as International Political Sociology - will either venture into a broader thematic world in which neorealism and neoliberalism will be of no avail or sociologists will make further inroads beyond the nation-state frontiers and into what IR scholars consider their preserve. Or a combination of both.

Any attempt to explain the 'principle of mutual ignorance' shows how an enormous research agenda emerges. One way to begin is to explore the substantial differences between the two disciplines and their institutional histories, which are disparate, at least in the US, but probably elsewhere too. One discipline was born out of social activism, while the other grew out of legal scholarship and was practiced by educated elites; it would be difficult to find an IR parallel to the engagement of progressive social workers. In sociology, before advanced degrees existed, pioneers came from a variety of backgrounds, but mainly philosophy, although some of the most important ones made their careers as political economists. By contrast, in IR, political scientists and, in particular, state theorists abounded, particularly during the early 20th century. The labor markets for both disciplines are also different, as are the opportunities for consultancy available to professors and practitioners in sociology and in IR. That these differences 
in employment and consultancy opportunities should have not intellectual consequences is almost unthinkable. Sociology experienced an almost-debacle around 1980 (Turner, 2014), an experience unknown to IR, although one would think that the fall of the Berlin Wall could have brought the IR enterprise to the brink of closure. Finally, it is possible to identify an intriguing pattern that concerns major figures, like Gabriel Almond, Edward Shils, and even Karl Deutsch and others who worked for the US government during WWII, according to which revolving doors could take sociologists (and political scientists) to multidisciplinary area studies and even comparative politics, but never to fully fledged IR careers. This could explain why contemporary social theory, and some major methodological innovations incepted in the 1940s, such as international survey research, came to maturity in sociology and comparative politics rather than in IR, underlining the dependence of the latter on the first and the almost complete irrelevance of IR for sociology.

\section{Note}

1 The chapter benefited from critical comments from Tine Hanrieder and Klaus Schlichte. Magdalena Jetschgo generously helped us with the bibliometric research. We would like to thank them all. However, the sole responsibility for the chapter is ours.

\section{REFERENCES}

Adler, Emanuel. 2013. 'Constructivism and International Relations'. In Handbook of International Relations, edited by Walter Carlsnaes, Beth A. Simmons, and Thomas Risse, 112-44. London: Sage.

Albert, Mathias, and Barry Buzan. 2013. 'International Relations Theory and the "Social Whole": Encounters and Gaps Between IR and Sociology'. International Political Sociology 7 (2): 117-35. doi:10.1111/ ips. 12013.
Albert, Mathias, Barry Buzan, and Michael Zürn, eds. 2013. Bringing Sociology to International Relations: World Politics as Differentiation Theory. Cambridge: Cambridge University Press.

Aron, Raymond. 1962. Paix et guerre entre les nations. Paris: Calmann-Lévy.

Ashley, Richard K. 1984. 'The Poverty of Neorealism'. International Organization 38 (2): 225-86.

Barnett, Michael N., and Martha Finnemore. 1999. 'The Politics, Power, and Pathologies of International Organizations'. International Organization, 53 (4): 699-732.

Barnett, Michael N., and Martha Finnemore. 2004. Rules for the World: International Organizations in Global Politics. Ithaca, NY: Cornell University Press.

Baron, Ilan Zvi. 2014. 'The Continuing Failure of International Relations and the Challenges of Disciplinary Boundaries'. Millennium - Journal of International Studies 43 (1): 224-44. doi:10.1177/0305829814541834.

Bayart, Jean-François. 2004. Le Gouvernement Du Monde: Une Critique Politique de La Globalisation. Paris: Fayard.

Bell, Duncan. 2001. 'International Relations: The Dawn of a Historiographical Turn?' The British Journal of Politics \& International Relations 3 (1): 115-26. doi:10.1111/1467-856X.00053.

Bigo, Didier. 1996. Polices en réseaux: I'éxpérience européenne. Paris: Presses de la Fondation nationale des sciences politiques.

Bigo, Didier. 2011. 'Pierre Bourdieu and International Relations: Power of Practices, Practices of Power'. International Political Sociology 5 (3): 225-58. doi:10.1111/ j.1749-5687.2011.00132.x.

Bliesemann de Guevara, Berit, ed. 2012. Statebuilding and State-Formation: The Political Sociology of Intervention. London: Routledge.

Breitenbauch, Henrik. 2013. International Relations in France: Writing between Discipline and State. Abingdon: Routledge.

Bull, Hedley. 1977. The Anarchical Society: A Study of Order in World Politics. New York: Columbia University Press.

Butterfield, Herbert, and Martin Wight. 1966. Diplomatic Investigations: Essays in the Theory of International Politics. Cambridge: Harvard University Press. 
Buzan, Barry. 2004. From International to World Society?: English School Theory and the Social Structure of Globalisation. New York: Cambridge University Press.

Buzan, Barry, and Mathias Albert. 2010. 'Differentiation: A Sociological Approach to International Relations Theory'. European Journal of International Relations 16 (3): 315-37. doi:10.1177/1354066109350064.

Buzan, Barry, Charles Jones, and Richard Little. 1993. The Logic of Anarchy. Neorealism to Structural Realism. New York: Columbia University Press.

Buzan, Barry, and Richard Little. 2000. International Systems in World History: Remaking the Study of International Relations. Oxford; New York: Oxford University Press.

Buzan, Barry, Ole Wæver, and Jaap de Wilde. 1998. Security: A New Framework for Analysis. Boulder, CO: Lynne Rienner Pub.

Carvalho, Benjamin de, Halvard Leira, and John M. Hobson. 2011. 'The Big Bangs of IR: The Myths That Your Teachers Still Tell You about 1648 and 1919'. Millennium - Journal of International Studies 39 (3): 735-58.

Cohen, Jere, Lawrence E. Hazelrigg, and Whitney Pope. 1975. 'De-Parsonizing Weber: A Critique of Parsons' Interpretation of Weber's Sociology'. American Sociological Review 40 (2): 229-41.

Cox, Robert W. 1981. 'Social Forces, States and World Orders: Beyond International Relations Theory'. Millennium - Journal of International Studies 10 (2): 126-55. doi:10.1177/030582 98810100020501.

Cox, Robert W. 1983. 'Gramsci, Hegemony and International Relations: An Essay in Method'. Millennium - Journal of International Studies 12 (2): 162-75.

Dahl, Robert A. 1961a. 'The Behavioral Approach in Political Science: Epitaph for a Monument to a Successful Protest'. American Political Science Review 55 (4): 763-72.

Dahl, Robert A. 1961b. Who Governs? Democracy and Power in an American City. New Haven: Yale University Press.

Donnelly, Jack. 2008. 'The Ethics of Realism'. In The Oxford Handbook of International Relations, edited by Christian Reus-Smit and Duncan Snidal, 150-62. Oxford \& New York: Oxford University Press.
Dunne, Tim, Lene Hansen, and Colin Wight, eds. 2013. Special Issue: The End of International Relations Theory?. Vol. 19. 3 vols. European Journal of International Relations. Retrieved from http://ejt.sagepub. com/content/19/3/405

Dunne, Timothy. 1998. Inventing International Society: A History of the English School. Basingstoke: Macmillan.

Easton, David. 1965. A Systems Analysis of Political Life. New York: Wiley.

Easton, David. 1969. 'The New Revolution in Political Science'. American Political Science Review 63 (4): 1051-61.

Ferguson, Yale H., and Richard W. Mansbach. 2016. 'Reflections on the "Third Debate" > International Studies Association'. Retrieved on October 4 from http://www.isanet.org/ Publications/ISQ/Posts/ID/312/Reflections-onthe-Third-Debate

Friedrichs, Jörg, and Ole Wæver. 2009. 'Western Europe: Structure and Strategy at the National and Regional Levels'. In International Relations Scholarship around the World, edited by Arlene B. Tickner and Ole Wæver, 261-86. Abingdon, Oxon \& New York: Routledge.

Gilman, Nils. 2003. Mandarins of the Future: Modernization Theory in Cold War America. Baltimore: Johns Hopkins University Press.

Goldstein, Judith, and Robert O. Keohane. 1993. 'Ideas and Foreign Policy: An Analytical Framework'. In Ideas and Foreign Policy. Beliefs, Institutions, and Political Change, edited by Judith Goldstein and Robert O. Keohane, 330. Ithaca: Cornell University Press.

Gunnell, John G. 1991. 'The Historiography of American Political Science'. In The Development of Political Science: A Comparative Survey, edited by David Easton, John G. Gunnell, and Luigi Graziano, 13-33. London \& New York: Routledge.

Gunnell, John G. 2013. 'The Reconstitution of Political Theory: David Easton, Behavioralism, and the Long Road to System'. Journal of the History of the Behavioral Sciences 49 (2): 190-210. doi:10.1002/jhbs.21593.

Gurian, Waldemar. 1946. 'On the Study of International Relations'. The Review of Politics 8 (3): 275-82.

Guzzini, Stefano. 1998. Realism in International Relations and International Political Economy. 
The Continuing Story of a Death Foretold. New International Relations Series. London: Routledge.

Halliday, Fred. 1985. 'A "Crisis" of International Relations?'. International Relations 8 (4): 40712. doi:10.1177/004711788500800406.

Halliday, Fred. 1994. Rethinking International Relations. Vancouver: UBC Press.

Hardt, Michael, and Antonio Negri. 2000. Empire. Cambridge: Harvard University Press.

Hensell, Stephan. 2016. 'Staff and Status in International Bureaucracies. A Weberian Perspective on the EU Civil Service'. Cambridge Review of International Affairs 29 (3), early view.

Hilferding, Rudolf. 1981 [1910]. Finance Capital. A Study of the Latest Phase of Capitalist Development. Edited by Thomas B. Bottomore. Translated by Morris Watnick and Sam Gordon. London: Routledge \& Kegan Paul.

Hobden, Stephen, and John M. Hobson, eds. 2002. Historical Sociology of International Relations. Cambridge \& New York: Cambridge University Press.

Hobson, John. A. 1902. Imperialism. A Study. New York: James Pott.

Hobson, John M. 2002. 'What's at Stake in "Bringing Historical Sociology Back" into International Relations? Transcending "Chronofetishism" and "Tempocentrism" in International Relations'. In Historical Sociology of International Relations, edited by Stephen Hobden and John M. Hobson, 3-41. Cambridge, UK; New York: Cambridge University Press.

Hobson, John M. 2012. The Eurocentric Conception of World Politics: Western International Theory, 1760-2010. Cambridge, UK; New York: Cambridge University Press.

Hobson, John M., George Lawson, and Justin Rosenberg. 2010. 'Historical Sociology'. In The International Studies Encyclopedia, edited by Robert A. Denemark, 12: 3357-75. Chichester \& Malden, MA: Wiley-Blackwell.

Hoffmann, Stanley. 1977. 'An American Social Science: International Relations'. Daedalus 106 (3): 41-60.

Kaplan, Morton A. 1957. System and Process in International Politics. New York: Wiley.

Kaplan, Morton A. 1966. 'The New Great Debate: Traditionalism vs. Science in
International Relations'. World Politics 19 (1): 1-20. doi:10.2307/2009840.

Katzenstein, Peter J, ed. 1996. The Culture of National Security: Norms and Identity in World Politics. New York: Columbia University Press.

Keohane, Robert O. 1984. After Hegemony. Cooperation and Discord in the World Political Economy. Princeton, New Jersey: Princeton University.

Keohane, Robert O. 1988. 'International Institutions: Two Approaches'. International Studies Quarterly 32 (4): 379-96. doi:10.2307/2600589.

Keohane, Robert O. 1995. 'Hobbes's Dilemma and Institutional Change in World Politics: Sovereignty in International Society'. In Whose World Order? Uneven Globalization and the End of the Cold War, edited by Hans-Henrik Holm, 63-87. Boulder, CO: Westview Press.

Kratochwil, Friedrich. 1988. 'Regimes, Interpretation and the "Science" of Politics: A Reappraisal'. Millennium 17 (2): 263-84.

Kratochwil, Friedrich. 2008. 'Sociological Approaches'. In The Oxford Handbook of International Relations, edited by Christian Reus-Smit and Duncan Snidal, 444-61. Oxford \& New York: Oxford University Press. Krippendorff, Ekkehard. 1975. Internationales System als Geschichte. Frankfurt am Main: Campus Verl.

Krippendorff, Ekkehart. 1972. Probleme der Internationalen Beziehungen: Essays. Frankfurt am Main: Suhrkamp.

Lacher, Hannes. 2006. Beyond Globalization: Capitalism, Territoriality and the International Relations of Modernity. London; New York: Routledge.

Lapid, Yosef. 1989. 'The Third Debate: On the Prospects of International Theory in a PostPositivist Era'. International Studies Quarterly 33 (3): 235-54. doi:10.2307/2600457.

Lebow, Richard N. 2013. 'Classical Realism'. In International Relations Theories: Discipline and Diversity, edited by Timothy Dunne, Milja Kurki, and Steve Smith, 59-76. Oxford: Oxford University Press.

Lenin, Vladimir Ilich. 1937 [1916]. Imperialism, the Highest Stage of Capitalism. New York: International publishers.

Leonard, Robert. 2010. Von Neumann, Morgenstern, and the Creation of Game 
Theory: From Chess to Social Science, 19001960. New York: Cambridge University Press. Linklater, Andrew. 1989. Beyond Realism and Marxism: Critical Theory and International Relations. New York: St. Martin's Press.

Linklater, Andrew. 2011. The Problem of Harm in World Politics: Theoretical Investigations. Cambridge; New York: Cambridge University Press.

Long, David, and Brian C. Schmidt. 2006. Imperialism and Internationalism in the Discipline of International Relations. SUNY Press.

Lottholz, Philipp, and Nicolas Lemay-Hébert. 2016. 'Re-Reading Weber, Re-Conceptualizing State-Building: From Neo-Weberian to PostWeberian Approaches to State, Legitimacy and State-Building'. Cambridge Review of International Affairs, 29 (3) early view.

Maliniak, Daniel, Susan Peterson, and Michael J. Tierney. 2012. TRIP around the World: Teaching, Research, and Policy Views of International Relations Faculty in 20 Countries. Williamsburg, VA: The Institute for the Theory and Practice of International Relations, The College of William and Mary.

Martin, Lisa L., and Beth A. Simmons. 2013. 'International Organizations and Institutions'. In Handbook of International Relations, edited by Walter Carlsnaes, Beth A. Simmons, and Thomas Risse, 325-51. London: Sage.

Marx, Karl, and Friedrich Engels. 1959 [1848]. 'Manifest der Kommunistischen Partei'. In Werke, 4: 459-93. Berlin: Dietz.

Mateos, Salvador, and Álvaro Morcillo Laiz. 2017. 'The Principle of Mutual Ignorance. Sociology in IR and Vice Versa'. Mexico City, forthcoming.

Milner, Helen. 1991. 'The Assumption of Anarchy in International Relations Theory: A Critique'. Review of International Studies 17 (1): 67-85. doi:10.1017/S026021050011232X.

Moravcsik, Andrew. 2008. 'The New Liberalism'. In The Oxford Handbook of International Relations, edited by Christian Reus-Smit and Duncan Snidal, 234-54. Oxford \& New York: Oxford University Press.

Morcillo Laiz, Álvaro, and Klaus Schlichte. 2015. 'Another Weber: State, Associations, and Domination in International Relations'. Cambridge Review of International Affairs 29 (3), early view.
Morcillo Laiz, Álvaro, and Klaus Schlichte. 2016. 'Rationality and International Domination: Revisiting Max Weber'. International Political Sociology 10 (2): 168-84.

Morgenthau, Hans J. 1946. Scientific Man versus Power Politics. Chicago, ILL: University of Chicago Press.

Morgenthau, Hans J. 1954. Politics Among Nations. The Struggle for Power and Peace. 2nd ed. New York: Knopf.

Murphy, Craig. 2006. The United Nations Development Programme: A Better Way? Cambridge \& New York: Cambridge University Press.

Norkus, Zenonas. 2000. 'Max Weber's Interpretive Sociology and Rational Choice Approach'. Rationality and Society 12 (3): 259-82. doi:10.1177/104346300012003001.

Onuf, Nicholas G. 1989. World of Our Making: Rules and Rule in Social Theory and International Relations. Columbia, SC: University of South Carolina.

Rae, Heather. 2002. State Identities and the Homogenisation of Peoples. Cambridge: Cambridge University Press.

Reus-Smit, Christian. 2013. Individual Rights and the Making of the International System. Cambridge: Cambridge University Press.

Risse, Thomas. 2000. "'Let's Argue!": Communicative Action in World Politics'. International Organization 54 (1): 1-39. doi:10.1162/002081800551109.

Rosenberg, Justin. 1994. The Empire of Civil Society. A Critique of the Realist Theory of International Relations. London \& New York: Verso.

Rosenberg, Justin. 2013. 'The "Philosophical Premises" of Uneven and Combined Development'. Review of International Studies 39 (3): 569-97. doi:10.1017/ S0260210512000381.

Roth, Guenther. 1971. "“Value-Neutrality" in Germany and the United States'. In Scholarship and Partisanship: Essays on Max Weber, by Reinhard Bendix and Guenther Roth, 156-69. Berkeley: University of California Press.

Schmidt, Brian C. 1998. The Political Discourse of Anarchy. A Disciplinary History of International Relations. Albany: State University of New York Press.

Schmidt, Brian C. 2008. 'Political Science and the American Empire: A Disciplinary History 
of the "Politics" Section and the Discourse of Imperialism and Colonialism'. International Politics 45 (6): 675-87. doi:10.1057/ ip.2008.29.

Schmidt, Brian C. 2010. 'The History of International Studies'. In The International Studies Encyclopedia, edited by Robert Allen Denemark, 12: 3418-38. Chichester \& Malden, MA: Wiley-Blackwell.

Schmidt, Brian C. 2013. 'On the History and Historiography of International Relations'. In Handbook of International Relations, edited by Walter Carlsnaes, Thomas Risse, and Beth A. Simmons, 3-28. London \& Thousand Oaks, CA: Sage.

Seabrooke, Leonard, and Emelie Rebecca Nilsson. 2015. 'Professional Skills in International Financial Surveillance: Assessing Change in IMF Policy Teams'. Governance 28 (2): 237-54. doi:10.1111/gove.12106.

Seabrooke, Leonard, and Duncan Wigan. 2016. 'Powering Ideas through Expertise: Professionals in Global Tax Battles'. Journal of European Public Policy 23 (3): 357-74.

Senghaas, Dieter. 1969. Abschreckung und Frieden: Studien zur Kritik Organisierter Friedlosigkeit. Frankfurt am Main: Europäische Verlagsanstalt.

Senghaas, Dieter., ed. 1971. Kritische Friedensforschung. Frankfurt am Main: Suhrkamp.

Senghaas, Dieter., ed. 1974. Peripherer Kapitalismus: Analysen über Abhängigkeit und Unterentwicklung. Frankfurt am Main: Suhrkamp.

Sills, David L. 1968. International Encyclopedia of the Social Sciences. New York: Macmillan.

Simmerl, Georg, and Michael Zürn. 2016. 'Internationale Autorität'. ZIB Zeitschrift für Internationale Beziehungen 23 (1): 38-70. doi:10.5771/0946-7165-2016-1-38.

Smelser, Neil J., and Paul B. Balter, eds. 2001. International Encyclopedia of the Social \& Behavioral Sciences. 26 vols. Amsterdam \& New York: Elsevier.

Smith, Michael J. 1986. Realist Thought from Weber to Kissinger. Baton Rouge: Louisiana State University.

Smith, Steve. 2000. 'The Discipline of International Relations: Still an American Social Science?' The British Journal of Politics \& International Relations 2 (3): 374-402.
Snidal, Duncan. 2008. 'Rational Choice and International Relations'. In The Sage Handbook of International Relations, edited by Walter Carlsnaes, Thomas Risse, and Beth A. Simmons, 85-111. Oxford \& New York: Oxford University Press.

Steffek, Jens. 2015. 'Max Weber, Modernity and the Project of International Organization'. Cambridge Review of International Affairs, 29 (3), early view.

Steinmetz, George, ed. 2013a. Sociology \& Empire: The Imperial Entanglements of a Discipline. Durham, NC: Duke University Press.

Steinmetz, George. 2013b. 'The Sociology of Empires, Colonialism, and Postcolonialism'. Annual Review of Sociology 40 (1): 77-103.

Stetter, Stephan. 2013. Ordnung und Wandel in der Weltpolitik: Konturen einer Soziologie der Internationalen Beziehungen. BadenBaden: Nomos.

Subotic, Jelena. 2017. 'Constructivism as Professional Practice in the USA Academy'. PS: Political Science and Politics 50 (1): 84-88.

Teschke, Benno. 2003. The Myth of 1648 : Class, Geopolitics, and the Making of Modern International Relations. London; New York: Verso.

Teschke, Benno. 2008. 'Marxism'. In The Oxford Handbook of International Relations, edited by Christian Reus-Smit and Duncan Snidal, 163-87. Oxford \& New York: Oxford University Press.

Thompson, Kenneth W. 1955. 'Toward a Theory of International Politics'. American Political Science Review 49 (3): 733-46. doi:10.2307/1951435.

Tickner, Arlene B., and Ole Wæver, eds. 2009. International Relations Scholarship around the World. Worlding beyond the West. Abingdon, Oxon; New York: Routledge.

Tickner, J. Ann. 2014. A Feminist Voyage through International Relations.

Tiryakian, Edward A. 1966. 'A Problem for the Sociology of Knowledge. The Mutual Unawareness of Émile Durkheim and Max Weber'. Archives Européennes de Sociologie/ European Journal of Sociology/Europäisches Archiv für Soziologie 7 (2): 330-36.

Tribe, Keith. 2007. 'Talcott Parsons as Translator of Max Weber's Basic Sociological Categories'. History of European Ideas 33: 212-33. 
Trotsky, Leon. 1932. The History of the Russian Revolution. Translated by Max Eastman. New York: Simon and Schuster.

Turner, Stephen P. 2008. 'Hans J. Morgenthau and the Legacy of Max Weber'. In Political Thought and International Relations: Variations on a Realist Theme, edited by Duncan Bell, 63-82. Oxford; New York: Oxford University Press.

Turner, Stephen P. 2014. American Sociology. From Pre-Disciplinary to Post-Normal. Basingstoke \& New York: Palgrave Macmillan. Turner, Stephen P., and George Mazur. 2009. 'Morgenthau as a Weberian Methodologist'. European Journal of International Relations 15 (3):477-504. doi:10.1177/1354066109338242.

Vitalis, Robert. 2015. White World Order, Black Power Politics: The Birth of American International Relations. The United States in the World. Ithaca, NY: Cornell University Press.

Wæver, Ole. 1996. 'The Rise and Fall of InterParadigm Debate'. In International Theory. Positivism and Beyond, edited by Steve Smith, Ken Booth, and Marysia Zalewski, 149-85. Cambridge; New York: Cambridge University Press.

Wæver, Ole. 1998. 'The Sociology of a Not So International Discipline: American and European Developments in International Relations'. International Organization 52 (4): 687-727.

Wæver, Ole. 2010. 'Towards a Political Sociology of Security Studies'. Security Dialogue 41 (6): 649-58. doi:10.1177/0967010610388213.
Wæver, Ole. 2011. 'Politics, Security, Theory'. Security Dialogue 42 (4-5): 465-80. doi: 10.1177/0967010611418718.

Wæver, Ole. 2013. 'Still a Discipline After All These Debates?' In International Relations Theories: Discipline and Diversity, edited by Timothy Dunne, Milja Kurki, and Steve Smith, 306-27. Oxford: Oxford University Press.

Wallerstein, Immanuel. 1974. The Modern World-System. New York: Academic Press.

Waltz, Kenneth. 1979. Theory of International Politics. New York: McGraw-Hill.

Weber, Max. 1994 [1919]. 'The Profession and Vocation of Politics'. In Political Writings, edited by Peter Lassman and Ronald Speirs, 309-69. New York: Cambridge University Press.

Wendt, Alexander. 1999. Social Theory of International Politics. New York \& Cambridge: Cambridge University Press.

Wohlforth, William C. 2008. 'Realism'. In The Oxford Handbook of International Relations, edited by Christian Reus-Smit and Duncan Snidal, 131-49. Oxford \& New York: Oxford University Press.

Wright, James D., ed. 2015. International Encyclopedia of the Social \& Behavioral Sciences. 26 vols. Amsterdam: Elsevier.

Zarakol, Ayse. 2017. 'TRIPping Constructivism'. PS: Political Science and Politics 50 (1): 75-78. 